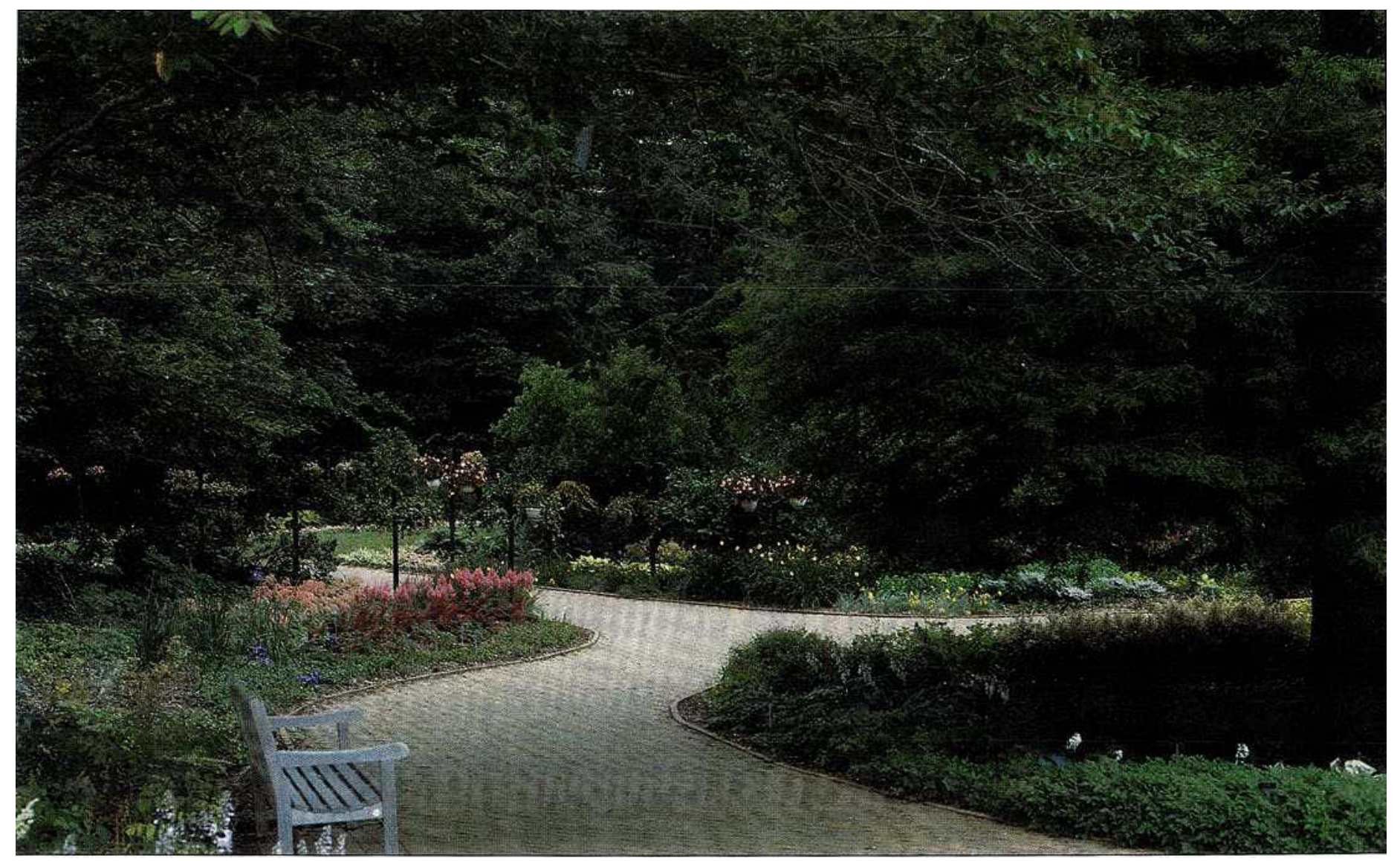

Urban horticultural center.

\title{
Environmental horticulture: "growth" industry in California
}

\author{
Dennis R. Pittenger $\square \quad$ Victor A. Gibeault $\square$. Steve T. Cockerham
}

\section{California's environmental horticul- ture industry has economic activity in excess of $\$ 7.2$ billion annually, but its numerous segments are not unified. University research and ex- tension activities could signifi- cantly assist in defining industry problems and extending practical solutions based on applied and ba- sic research.}

California is now the second most urbanized state in the nation, with $91 \%$ of its 30 million residents living in urban areas. The state is growing at a rate of 700,000 individuals a year, with population increases largest in Southern California, particularly San Diego, San Bernardino, Riverside and Los Angeles Counties. With the exception of San Francisco, all counties have recorded increased residents.
For the state's 27 million city-dwellers, California's urban landscapes are as essential to a quality lifestyle as the state's

famed coastlines and mountain slopes. Environmental horticulture is consequently a growing part of the state's economy. However, its structure, size and scope have not been well documented. It was the objective of this study to do so, and to quantify the industry's contribution to the economy of California.

Environmental horticulture is broadly defined as the industry which maintains and improves the functional use of plants in populated areas, and enhances ornamental production. It encompasses all non-production uses of plants and the commercial production of nursery and floriculture commodities. It includes the following three functional groups:

1) Production businesses that produce all stages and kinds of ornamental plants from seed to sod, and cuttings to cut flowers;
2) Service businesses that research, design, install, sell at the retail level, or care for ornamental plants:

3) Equipment and accessories businesses that produce and sell primary equipment or secondary accessories that support the production and service groups.

The end user is the beneficiary and consumer of this industry. That user can be a homeowner of a single or multi-family dwelling; a commercial enterprise such as a golf course, office building or an apart-

\begin{tabular}{|lc|}
\hline $\begin{array}{c}\text { TABLE 1. Wholesale sales volume for California } \\
\text { ornamental plant production in }\end{array}$ \\
\hline \hline & Value reported \\
\hline & million $\$$ \\
Turf & 13.1 \\
Floriculture & 712.7 \\
Landscape plants & 520.9 \\
Cuttings and propagation materials & 39.0 \\
Miscellaneous nursery products & 173.6 \\
Total product value & $\$ 1, \mathbf{4 5 9 . 3}$ \\
\hline
\end{tabular}


ment complex; or a public agency such as California Department of Transportation (Caltrans) or a state park. Figure 1 diagrams the functional relationships of the industry segments to the end user.

Principal data acquisition for this study was conducted by the Sacramento-based. consulting firm of Dangermond and Associates under the direction of a University of California, Riverside team. Production figures were provided by the State Agricultural Commission, employment figures by the Census Bureau and the Employment Development Department, and sales volume figures by the State Board of Equalization. Employment and wage statistics were obtained from the California Employment Development Department using Standard Industrial Classification (SIC) statistics. Employment, sales volume figures and other data are for 1987-88.

\section{Production of ornamental plants}

California leads the nation in the production of ornamental plants. The wholesale production data for floriculture, nursery and turf, as reported for 1987 by the State Agricultural Commission, are presented in table 1 . This information is based on a county by county reporting, and encompasses all the areas of ornamental plant production with which this study is concerned. The data are the cumulative totals in each category and are based on grower disclosure.

The total economic activity in 1987 for the production segment of environmental horticulture was nearly $\$ 1.5$ billion. The largest single category was floriculture and the smallest category was turfgrass sod production.

The production environmental horticulture industry employed an average of 28,834 people in 1987 , according to the California Employment Development Department (EDD). Total wages for that year exceeded $\$ 427$ million.

\section{Services related to ornamentals}

As shown in figure 1, the environmental horticulture industry can be segmented into five service areas: design, retail sales, installation, maintenance, and research/ education.

Design. Design of outdoor spaces with environmental horticulture products is done by licensed landscape architects, landscape designers, landscape contractors, employees of production nurseries, and end users. There are approximately 3,000 landscape architects in California. No gross receipts or sales volumes have been collected for this industry category. However, we estimated annual business activity of \$263 million from the 1987 payroll of $\$ 84.5$ million. The estimate was generated using a ratio of gross receipts to

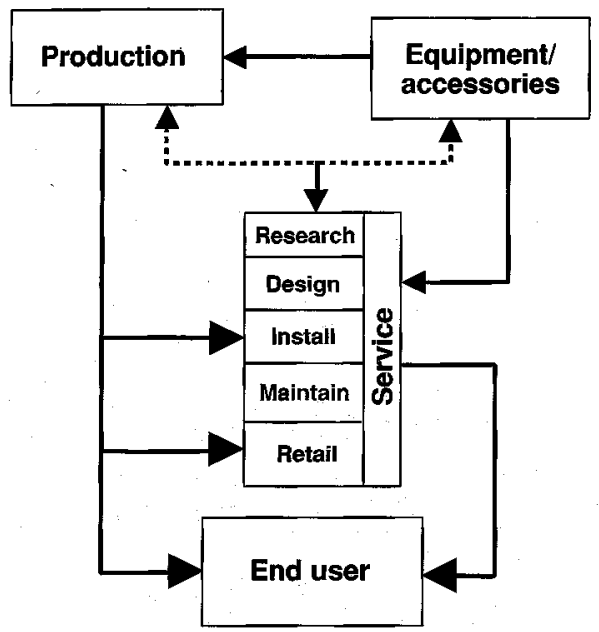

Figure 1. Functional relationships in the environmental horticulture industry.

payroll of 3.11:1. The ratio was determined using gross receipts and payroll figures from the 1978 Census of Agriculture. Employee numbers are given in table 2 .

Retail sales. The use of nursery, floriculture and turf plant materials by enduser groups greatly impacts the production segment of the environmental horticulture industry. Users dictate which plant species and the quantities and sizes of each that are produced. Services are dominated by retail sales of ornamental plants and garden supplies which totalled about $\$ 1.8$ billion in 1987. Figures for retail florists sales (1987) are $\$ 566$ million sold through 4,378 outlets. The general "garden supply" category had reported sales of $\$ 1.24$ billion in 1987 through 3,600 outlets. Not included in these retail sales figures are the values of plants, flowers and supplies sold through various types of department stores and grocery stores. There were 20,826 people employed in this industry category in 1987 with wages of \$245 million dollars, as given in table 2 .
Installation and maintenance. California requires licensing of landscape contractors, and there were about 6,000 such firms in 1987. Turfgrass installation and maintenance firms had a 1987 payroll of about $\$ 475$ million (Standard Industrial Classification SIC 0782), and firms that primarily installed and maintained trees and shrubs had a payroll of about $\$ 65$ million (SIC 0783). Gross receipts to payroll ratios were $3.76: 1$ and 2.76:1, respectively. Gross receipts were calculated to be $\$ 1.79$ billion for lawn and garden installation and maintenance and $\$ 180$ million for treeshrub installation and maintenance, with a total industry segment value of $\$ 1.97$ billion. There were 38,800 employees in 1987 in the installation and maintenance of environmental horticulture plant materials and sites.

Many public agencies conduct their own design, installation and/or maintenance of landscapes. The information available came directly from individual agencies or other extrapolations, as there is no statewide systematic reporting of payroll and other expenditures.

Caltrans managed over 21,000 acres of landscape and employed about $832 \mathrm{em}$ ployees at a cost of more than $\$ 41.5$ million in 1987.

Public parks typically cover large areas with only a limited portion intensely managed as a landscape setting. Excluding irrigation, it costs approximately $\$ 2.8$ million annually to maintain state park landscapes. City, county and district parks number 7,738 with over 157,000 acres of turf and ornamental plantings. Annual maintenance is about $\$ 837.2$ million.

The management of urban street trees is becoming an important function of local public agencies. A 1988 statewide survey by the California Department of Forestry and Fire Protection indicates that about 5.9 million trees are actively maintained in

\begin{tabular}{|c|c|c|c|}
\hline \multicolumn{4}{|c|}{ TABLE 2. Services summary } \\
\hline & $\begin{array}{c}\text { No. } \\
\text { employees }\end{array}$ & $\begin{array}{c}\text { Total } \\
\text { wages }\end{array}$ & $\begin{array}{l}\text { Gross } \\
\text { receipts }\end{array}$ \\
\hline & & & \\
\hline \multicolumn{4}{|l|}{ Component } \\
\hline and education & 125 & 1.8 & 1.8 \\
\hline Retail sales & 20,826 & 245.1 & $1,801.3$ \\
\hline Design & 4,161 & 84.5 & 262.9 \\
\hline \multicolumn{4}{|l|}{ Installation } \\
\hline and maintenance & 38,800 & 539.71 & $1,966.8$ \\
\hline Turf & 31,000 & 431.8 & \\
\hline Ornamentals & 7,800 & 107.9 & \\
\hline \multicolumn{4}{|l|}{ Public agencies } \\
\hline Caltrans & 832 & 41.5 & \\
\hline State parks & 85 & 2.5 & \\
\hline City and county & 22,490 & 753.4 & \\
\hline Urban trees & & 76.3 & \\
\hline \multicolumn{4}{|l|}{ Other } \\
\hline Schools & & & \\
\hline and public bldgs. & - & 一 & \\
\hline Public buildings & - & - & \\
\hline Golf courses & - & - & \\
\hline Total & 87,319 & $1,744.8$ & $\$ 4,032.8$ \\
\hline
\end{tabular}


California at an annual cost of $\$ 109$ million.

A major gap in available data is the landscape installation and maintenance costs or number of employees incurred by schools and other public agencies. There are no published figures available on these costs. Licensed landscape contractors have long complained of the presence of unlicensed contractors, and consider this unlicensed work to have a significant dollar value. Similarly, the approximately 900 golf courses in the state do not publicly report their turf and landscape maintenance and installation costs.

Residential landscape management costs are not directly reported or estimated, but many of these expenditures are represented in retail garden center sales and landscape contractor receipts. For example, a recent survey in San Diego County revealed that $10 \%$ of urban residents hire someone to carry out lawn services. How much of the value of this segment is lost in the reporting system is unknown.

Research and education. This category includes both private and public research activity and technical and university educational institutions. There are seven research and higher educational institutions that offer undergraduate and/or graduate programs in landscape architecture, environmental design or landscape horticulture in the University of California and California State University systems. In addition, the University of California Cooperative Extension employs academic personnel in environmental horticulture at three campuses and several county offices. Also, at least 35 community colleges and several private colleges have technical or vocational programs in environmental horticulture.

A number of agencies (water districts, California Department of Food and Agriculture, agricultural commission, etc.) also keep industry records, fund research projects, or conduct informal educational programs. The media, especially print, provides a great deal of information and education related to landscaping and turf management to homeowners and professionals in environmental horticulture. There is no data available to provide an estimate of the economic activity related to environmental horticulture that these agencies and firms generate.

Services summary. This component of the environmental horticulture industry is extremely large and complex, and there is much missing data or only rough estimates concerning the economic value of many segments. Table 2 provides a summary of the value of the segments discussed above. The total gross receipts of services that can be documented is slightly

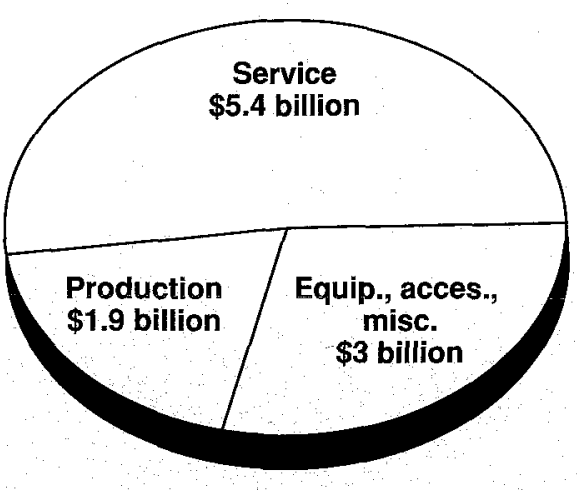

gasoline-rotaries for small areas, to large gang mowers capable of cutting a swath many feet wide. Edgers and string trimmers are also available in both

homeowner and professional size. Equipment has even been developed to both remove cores of turf for aeration and insert plugs of turf for new lawns.

\section{Summary and conclusions}

The environmental horticulture industry has a direct effect on the way most Californians live. It provides the medium for play in many recreational facilities; it modifies the environment to make life easier and more pleasant; it provides pleasing and functional home landscape. In addition, the industry has a significant direct economic impact on the state and a large indirect impact on the tourist economy.

This study has established the structure, value and size of the California environmental horticulture industry from available data. The production segment accounts for $\$ 1.46$ billion of product value and the service category was found to generate $\$ 4.03$ billion in gross receipts. Together, these total $\$ 5.5$ billion. Wages paid in addition to these two category segments totalled $\$ 2.2$ billion. Additionally, an equipment category was identified but the value could not be determined with present information. Likewise, industry service segments such as public facilities and golf courses have no available data. It is expected that these areas along with the equipment and accessories segment, would account for another $\$ 2$ to $\$ 4$ billion in value.

The California environmental horticulture industry is huge. Each of the industry segments tends to view itself independently from the others, so that the self-perception of the whole industry is neither clear nor unified. Industrywide concerns such as water availability, water quality, and pest and fertilizer management present opportunities for UC research and education that could benefit the entire state. By virtue of its size and importance to the state's economy and environment, the environmental horticulture industry qualifies as an appropriate focus for UC research and extension.

Cor the nursery industry. Generally, seed and cuttings are started in flats or liners and moved to larger pots, cans and boxes as they grow.

For large-scale landscape installation; some standard agricultural equipment has been modified to serve the special needs of environmental horticulture. Examples are tree spades, modified transport vehicles and hydromulch equipment.

Turf tends to be the most demanding of special equipment for maintenance. Mowers come in every conceivable shape and size from hand-push reels and electric- or
D. R. Pittenger is Extension Urban Horticulturist, V. A. Gibeault is Extension Environmental Horticulturist, and S. T. Cockerham is Superintendent, Agricultural Operations and Field Stations, UC Riverside.

This project was supported by the UCR Urban and Environmental Outreach Program. Bobbi Lyon of Dangermond and Associates researched the industry statistics. She was assisted by Richard Autio, UC Riverside Staff Research Associate. 